\title{
Shaping Citizenship: Chinese Family Law and Women
}

\author{
Margaret Y.K. Woo†
}

"I didn't want a divorce, but now I feel stronger, more self-reliant."

"The judge was pretty routine and businesslike.",

"I felt that my privacy had been invaded since I had to sign the divorce papers in the public reception area. No one seemed to care about my privacy or my sense of rights. ...",

Current law-and-development literature overwhelmingly urges the privatization of the economy and the establishment of a rule-of-law system, which endows citizens with rights and obligations, with the expectation that democracy and equality will inevitably follow. However, the above excerpts from my research interviewing female Chinese divorce litigants about their experiences in the Chinese court system capture a much more ambiguous effect of Chinese reforms on its citizens' sense of rights and entitlements. This article looks at China's recent legal reform through the eyes of male and female divorce litigants, and examines the kinds of citizenship rights that are being promoted through the Chinese court system. Are the changes occurring within the Chinese legal system encouraging a sense of citizenship rights and equality amongst its citizens? How has the Chinese court system benefited its most vulnerable citizens? Are Chinese legal reforms consistent with its citizens' conceptions of justice?

$\dagger$ Margaret Y.K. Woo is a professor of law at Northeastern University School of Law. This research was supported by the Northeastem University Research, Scholarship, and Development Fund. The author especially would like to thank Christina Gilmartin for her tireless collaboration in the collection of this data. An earlier version of this paper was presented at the 2001 annual meeting of the Law and Society Association in Vancouver, Canada, "The Reach of the Pacific Rim" symposium at the University of British Columbia, and the Women Sociologists Writing Group, and is part of a larger study on the role of civil litigation in China.

1. Interview with S-2 in Shanghai, China (May 13, 1998). Interviews were conducted with twentynine anonymous divorce litigants, S-1 through S-29, in Shanghai, China, from May 11 to June 5, 1998 (completed interview questionnaires on file with author). Interviews were also conducted with judges, lawyers, and others. Notes from these interviews are on file with the author. In order to protect those who were willing to speak, none of the names of interviewees will be revealed.

2. Interview with S-8 in Shanghai, China (May 19, 1998).

3. Interview with S-9 in Shanghai, China (May 19, 1998). 
This article focuses on divorce litigation in contemporary China through, among other data, in-depth interviews with twenty-nine divorce litigants. These interviews provide a rich source of insight into how Chinese women view themselves and the divorce process, and how they were affected by recent changes in the legal system. The article considers the ramifications of legal changes on conceptions of citizenship and the equality of citizenship rights for Chinese women.

This article especially focuses on whether the increasing use of the formal legal process has altered women's sense of entitlement and equality in Chinese society. The way Chinese women use the courts to enforce their rights also provides a lens into whether the law is being used as an instrument for citizen empowerment, and if so, how it is being used. For rule of law ideals truly to take root, the idea of legality and the use of legal instruments to settle rights and social problems must exist at the level of ordinary citizens.

\section{LAW, RIGHTS, AND CITIZENSHIP}

Historically, within the modern nation-state, the concept of citizenship has been the organizing principle between the state and its members. ${ }^{4}$ Through law and its prescriptions, the state defines and shapes the parameters of citizenship rights and obligations. Since marriage policy is often a tool used by the state to sculpt a nation's citizenry and moral standards, marriage policy and enforcement provide a critical lens through which one can examine citizenship rights in any nation-state. ${ }^{5}$

The basic beliefs regarding marriage held by both western political thought and eastern Confucian dictates and governance can be summarized in the following quotation. "Radiating outward, the structure of marriage organizes community life and facilitates the government's grasp on the populace."6 Therefore, examining the state's family policy, and particularly its policies toward marriage and the dissolution of marriage, can provide insight into issues of status and inequality, intimacy, and violence, and philosophies about proper governance. How family disputes are resolved lies at the intersection between the public and private spheres, the crucial nexus where the state's role of shaping citizenship takes place.

4. According to T. H. Marshall, citizenship is essentially a matter of ensuring that everyone is treated as a full and equal member of society. Such a sense of membership may be ensured by according people an increasing number of citizenship rights. As a signifier of personal status, citizenship equalizes the people by according its members increasing political, civil, and social rights. T.H. Marshall, Class, Citizenship AND Social DeVelopMent (1965); see also Will Kymlicka \& Wayne Norman, Return of the Citizen: A Survey of Recent Work on Citizenship Theory, in THEORIZING CITIZENSHIP 283, 283-322 (Ronald Beiner ed., 1995). (2000).

5. See generally NANCY F. COTT, PUBlic Vows: A History of MARRIAGE AND the NaTion

6. Id. at 1 . 
Since the inception of socialist China, the concept of citizenship seemed to be based largely on a corporatist view, in which citizens are defined by class and belong to collectivist social groups encouraged and promoted by the state. Women have been encouraged to think of themselves as workers, party members (of the CCP), members of youth groups (Youth League), or members of women's associations (such as the All China Women's Federation). ${ }^{7}$ Since the economic reforms of the 1980s and 1990s, however, a number of social developments, most significantly the development of a market-oriented economy and a marked increase in migration within China, began to change these views. ${ }^{8}$

The 1990s also witnessed an increase in the use of formal civil litigation in the Chinese courts, and a decrease in the use of informal dispute resolution, such as mediation by neighborhood committees and the work units. ${ }^{9}$ While community and group identity certainly have not disappeared, and community forms of dispute resolution still exist and are utilized, the increasing use of formal dispute resolution through court adjudication may have promoted a more individualized concept of citizenship. This is evident in the individualization and privatization of family and personal relations, exemplified by female litigants turning to the courts in divorce petitions. In turn, the courts are treating these divorce petitions as individual disputes between private parties instead of disputes between families and communities.

These trends, however, present some significant problems for female divorce litigants. In the public sphere of courts, where the private matter of divorce is litigated, the culture of transition breeds a confluence of tensions. ${ }^{10}$ When in court, female litigants are asked to act less like members of collectivist groups and more like individuals, with all the attendant benefits and pitfalls of asserting individual rights. Thus, the divorce litigation process may be heightening women's sense of individual entitlement, but at the same time, lowering women's sense of collective well-being. Several factors have contributed to this process, including economic reforms, geographical migration of women, migration by women from the public to the private sector,

7. For a comprehensive treatment of the changing status of Chinese women in the communist state, see CHRISTINA GILMARTIN ET AL., ENGENDERING CHINA: WOMEN, CULTURE AND THE STATE (1994).

8. See Dorothy J. Solinger, Contesting Citizenship in URBan China (1999) (examining ways in which migrant workers create their own labor markets and utilize markets to scrape together services central to survival in the cities, and in this process, deprived the communist state of its old ability to control and distribute its work force; concluding that in modern China, there is now a virtual layering of types of citizens in cities: true citizens, second-class citizens, ersatz citizens (outside the state), and non-citizens; and observing that each of these groups fares quite differently in the transition era).

9. See Stanley B. Lubman, Bird in a Cage: legal Reform in China After Mao 224 (1999).

10. See SUSAN M. OKIN, JUSTICE, GENDER AND THE FAMILY 129 (1989) (pointing out how the exclusion of the domestic from justice theories and the definition of the private sphere act to legitimate hierarchy and subordination in domestic relations). 
marriage law reform, and other social reforms. I will discuss each of these factors at length.

\section{HOW RECENT ECONOMIC REFORMS ARE SHAPING WOMEN'S OPPORTUNITIES AND EXPERIENCES}

As economic reforms and reliance on the market deepen, Chinese women's social status has increased in some ways, but decreased in others. ${ }^{11}$ Since the start of China's economic reforms and its re-entry into the global economy in the 1980 s, a number of social problems have emerged or reemerged, which threaten Chinese women's status and well-being, including their rights as equal citizens in the Chinese state. ${ }^{12}$ While the market-oriented economy has offered women greater mobility and freedom, such mobility has also resulted in greater threats for women at home and in the workplace. ${ }^{13}$

As I have written previously, ${ }^{14}$ the problems may be traced to a "commodification of the feminine" and take form in two contrasting trends. First, there has been a geographical migration in which Chinese women are traveling out of their localities for labor and for marriage, thereby transcending the local in favor of the regional and national. ${ }^{15}$ Second, there has been a public- to private-sector migration, in which female workers are encouraged to leave the state-sector workplace and enter the private sphere of the home and hearth. ${ }^{16}$ Both of these trends have resulted in greater isolation for women, higher incidence of poor health and suicide, greater threats of violence against women both in the family and the workplace, and greater family instability, including higher rates of divorce. ${ }^{17}$

\section{A. The Geographical Migration}

The first of these trends, the outward migration of Chinese women from local to regional to national, is a recent phenomenon. ${ }^{18}$ Over the past decade, China has literally become a nation in migration; Chinese sources report that

11. See generally Ann Jordan, Human Rights, Violence Against Women, and Economic Development (The People's Republic of China's Experience), COLUM. J. GENDER \& L. 216, 216-72 (1996).

12. See generally Margaret Y.K. Woo, Law and the Gendered Citizen, in CHANGING CONCEPTS OF CITIZENSHIP IN CONTEMPORARY CHINA 308-29 (Elizabeth Perty \& Merle Goldman eds., 2002)

13. Id.; See also Pun Ngai, Becoming Dagongmei [Laboring Sisters]: The Politics of Identity and Difference in Reform China, 42 CHINA J. I, 1-20 (July 1999).

14. Woo, supra note 12 , at 308-29.

15. Delia Davin, International Migration AND Contemporary ChINa 138 (1999); Christina Gilmartin \& Tan Lin, Where Have All the Rural Women Gone? Marriage Migrations in Contemporary China, in GENDER TRANSFORMATions IN EAST ASIA (Esther Chow \& C.K. Lee eds., 2000).

16. See Woo, supra note 12 , at 312-14.

17. Id.

18. For a detailed study of the China's migrants, see SOLINGER, supra note 8. 
close to 40 million women have given up farming for industrial-sector labor. ${ }^{19}$ Among these millions are the women, collectively known as dagongmei [laboring sisters], who have migrated to cities for work within the exploding numbers of foreign-invested, township, and privately-owned enterprises. ${ }^{20}$ Female workers constitute the majority of migrant workers in the explosion of these enterprises, which have been the focus of economic reforms. In some factories in the special economic zones, they constitute ninety percent of the labor force. ${ }^{21}$

By placing young, uneducated rural women under the authority of urban male supervisors, this outward labor migration renders women especially vulnerable to male exploitation, particularly economic and sexual abuse. ${ }^{22}$ Moreover, since these migrating women often take non-contractual, less desirable, temporary jobs without urban residence registration, they work without the social benefits normally guaranteed to state workers. ${ }^{23}$ While it may be argued that such jobs are better than no jobs at all, these jobs create societal stratification, with female workers consistently on the bottom rung. The combination of abusive bosses and limited state benefits thus subjects women to poor working conditions, discrimination, sexual abuse, and harassment. $^{24}$

Even in the best circumstances, out-migrating women cannot significantly draw on the support of their natal families, resulting in greater isolation and risk of abuse. This is particularly salient for rural women, who migrate outward from poor inner rural areas to more prosperous regional centers for marriage. ${ }^{25}$ Indeed, about thirty percent of Chinese women who migrate do so to marry. ${ }^{26}$ This migration is fueled by the resurgent practice of buying and selling rural women as brides, a practice the government disapproves of, but is unable to halt. ${ }^{27}$ At China's borders, where supplies are the highest, a young woman can

19. China; Country Gender Review, E. AsIA ENVTL \& Soc. Dev. UNIT, WORLD BanK, June 2002, at 15, available at www.worldbank.org.cn/English/content/gender-en.pdf. By the 1990s, close to 70million rural people had migrated to the cities for jobs, about two thirds of them men and one third women. In 2001, the estimated migrant population was 105 million. See also Zhang Ye, Migrant Women Workers and the Emerging Civil Society in China, ASIA FOUND., 2001 (noting that the 2000 national population census estimated that more than sixty percent of the over ten-million migrant laborers in Guangdong Province were women).

20. Pun Ngai, supra note 13, at 1-20.

21. Jordan, supra note 11 , at 216.

22. Id.

23. Lucy A.Williams \& Margaret Y.K. Woo, The 'Worthy' Unemployed: Societal Stratification and Unemployment Insurance Programs in China and the United States, 33 COLUM. J. TRANSNAT'L. L. 457, 510-11 (1995).

24. CHINA RIGHTS FORUM, EMPLOYMENT: THREATS TO WOMEN'S ECONOMIC INDEPENDENCE 5055 (Spring 1999).

25. DAVIN, supra note 15 ; Gilmartin \& Lin, supra note 15.

26. DAVIN, supra note 15; Gilmartin \& Lin, supra note 15

27. See generally, CHINA RIGHTS FORUM, SUPPRESSION OF TRAFFICKING IN WOMEN 42 (Spring 1999). According to official figures, in 1996, the police arrested 14,709 people in 8,290 trafficking 
command prices ranging from $\$ 250$ to $\$ 800 .^{28}$ The buying and selling of rural women represents a literal example of the commodification of women. ${ }^{29}$

\section{B. The Public Sector Migration}

The second form of migration taking place in China is the reverse migration of women from the public to the private sphere. This has resulted in a decline in women's participation in the formal political sphere workplace. ${ }^{30}$ China's economic reforms have led to redundancies in the workforce, with female workers bearing the brunt of this change. ${ }^{31}$ Women are often the last to be hired and first to be laid off. ${ }^{32}$ By the end of 1997, about fifty-three percent of the 5.768 million jobless people who had registered with their local governments were women. ${ }^{33}$ Official statistics indicate that in 1998, some forty-eight females were laid off for every forty males laid off. ${ }^{34}$ While constituting only thirty-nine percent of China's workforce, in regions such as Liaoning Province, women constituted nearly sixty-two percent of its nearly one-million laid-off workers. ${ }^{35}$ Moreover, seventy-five percent of the women laid off were still unemployed after one year, compared to fifty percent of their male counterparts. ${ }^{36}$

Despite women's escalating presence in the market-oriented economy, a gendered wage gap remains. In 1999, female workers earned an average of

cases, involving 1,928 trafficking groups. As a result, 10,503 victims, including 1,563 children, were rescued. Unofficial figures are much higher.

28. The trafficking of women has developed into a lucrative international trade spanning all the way to Vietnam. See Samantha Marshall, Double Crossing: They Don't Say 'I Do' These Kidnap Victims Taken From Vietnam, WALL Sr. J., Aug. 3, 1999, at Al.

29. See generally Jordan, supra note 11.

30. Women's share of seats in the Central Committee of the CCP peaked at 10 percent in 1973 but fell to about 5 percent by 1997. Almost no women sit on the most important CCP decision-making body, the Politbureau. Female share of the Standing Committee of the National People's Congress similarly peaked at 25 percent in 1975 , and declined to about 10 percent in 1998 . See China; Country Gender Review, supra note 19, at 18. As of 1997, China had just three female ministers and fourteen deputy vice ministers in the central government, 23 female vice provincial govemors, and 375 female mayors or deputy mayors in its 640-odd cities. Women also made up about 33 percent of the total government workforce. UNITED NATIONS, THE THIRD AND FOURTH NATIONAL REPORTS ON THE IMPLEMENTATION OF THE CONVENTION ON THE ELIMINATION OF ALL FORMS OF DISCRIMINATION AGAINST WOMEN: CHINA 3 (June 10, 1997), available at www.un.org/womenwatch/daw/cedaw/china.htm;

31. ChINA Rights Forum, supra note 24, at 50-55.

32. Id. The stated reason is that women are less desirable because they are more expensive, due to state-mandated maternity leave and other benefits. See Dusko Doder, The Old Sexism in New China, U.S. NEWS \& WORLD REP., Apr. 24, 1989, at 36. Economic reform and the resultant increase in wage variations have also contributed to further increases in gender-based wage differentials. See Margaret Maurer-Fazio et al., Inequality in the Rewards for Holding Up Half the Sky: Gender Wage Gaps in China's Urban Labour Market 1988-1994, 41 CHINA J. 55, 79 (Jan. 1999).

33. China to Help More Unemployed Women Find Jobs, XINHUA NEWS AGENCY (June 18, 1998).

34. China; Country Gender Review, supra note 19, at 15.

35. Id.

36. Elisabeth Rosenthal, In China 35 Plus and Female = Unemployable, N.Y. TIMES, Oct. 13, 1998, at A1. 
only seventy percent of men's pay, a sharp decrease from the eighty-three percent they earned in $1990 .{ }^{37}$ Women also comprised less than twelve percent of the country's managers in $1997^{38}$

\section{Private Sector Migration}

In the late 1980 s and early 1990 s, substantial rhetoric from official media developed, which encouraged women to serve the state by returning to the home and hearth. ${ }^{39}$ The expanding market-oriented economy further fueled this reverse migration by increasingly commodifying women as beauty objects. As beauty objects, women are viewed as consumers as well as products, who are relegated to the roles of wives and mistresses, rather than assuming roles as equal workers "holding up half the sky," 40 as they supposedly did during the Mao era. ${ }^{41}$ This view has led women to be valued simply for their youth and beauty and serves as a justification for denying them employment: in many cases, women at forty have been termed "too old" or "too fat" to be hired. ${ }^{42}$

The relocation of women to the private sphere of the home may be adding to women's vulnerability to violence and loss of financial autonomy. There are growing reports of family violence. ${ }^{43}$ According to a 1994 survey by the

37. China; Country Gender Review, supra note 19.

38. Id. at 14.

39. See Margaret Y.K. Woo, Biology and Equality: Challenge for Feminism in the Socialist and the Liberal State, 42 EMORY L.J. 143, 163-69 (1993). The rhetoric appearing in official media promoted women's domestic role as "good, natural, [and] inevitable," and encouraged them to "return home" to serve socialism as mothers and housewives. The argument given in support of this new idea was that there was a need for "women going home in the initial stage of socialism, ... women engaged in home duties in a kind of division of labor in society,... [and] the participation of women in the building of modemization." Wei Shiqing, Nuxing Chulu Yu Zhongguo de Weilai Ming Yun [Women's Outlet and China's Future, Part I, 5 ZHONGGUO FUNU [CHINESE WOMEN] 4-9 (1988). This "return home" rhetoric spurred a yearlong debate among scholars and readers in the official women's magazine Zhongguo Funu. In total, there were thirty-eight articles and letters published during 1988 on the efficacy and the effect of the "retum home" rhetoric on women's equality in China. The discussion began with the article by Zhang Jun \& Ma Wenrong, Da Qiu Zhuang [Funu Huijia] de Sisuo [Some Thoughts About the Da Qiu Village's Return Home Phenomenon], 1 ZHONGGUo FUNU [CHINESE WOMEN] 8-9 (1988).

40. Under Maoist interpretation of Marxist theory, women's liberation necessarily depended on women's full and equal participation in social production. The underlying assumption was that entry into the wage labor force would improve women's conditions and thus raise their confidence, power, and authority in both the public and domestic spheres. To address the inequality of women, the new government of the People's Republic of China quickly adopted a four-pronged strategy to "legislate for equality, introduce women into social production, introduce a new ideology of equality, and organize women to both redefine and forward their economic, social and political interests." ELISABETH CROLL, CHINESE WOMEN SINCE MAO 1 (1983).

41. See Woo, supra note 39 , at $148-51$.

42. These biases run so deep that many women seem to share their culture's low opinion of thernselves. Hence, Yang Xiyuan, a retired lawyer in Beijing, confided, "I met laid-off women workers from a textile factory who were given new jobs in a bank, but they learned too slowly. They were all in their forties, so their reactions were not very quick. They just couldn't do it fast enough." Rosenthal, supra note 36 , at $\mathrm{Al}$.

43. According to a recent study by the All China Women's Federation, domestic violence is a factor in 50-60\% of divorce cases. Ying Mingque Guiding Zhizhi Jiating Baoli-Quanguo Fulian Xiugai 
Beijing Society for Research on Marriage and the Family, one fifth of the wives among the 2,100 families surveyed had been abused by their spouses. ${ }^{44}$ Reports of extramarital affairs have grown, as has the number of divorces. ${ }^{45}$

\section{WOMEN'S CITIZENSHIP RIGHTS AS DEFINED THROUGH THE MARRIAGE LAWS}

The economic and physical migration of women has increased their geographical dislocation and correspondingly impacted their social identities. This has reflected itself in the way women view marriage, their role in the family, and their role vis a vis the state as they attempt to maneuver through the regulations dealing with marriage and divorce.

\section{A. The Impact of the Marriage Law of 1950 and Other Cultural Reforms on Traditional Chinese Marriage Customs}

In traditional China, marriage was the result of an agreement between two families rather than between two individuals. ${ }^{46}$ Similarly, divorce was also a matter negotiated by the families. ${ }^{47}$ This pattern began to change when the newly-established People's Republic instituted the Marriage Law of $1950{ }^{48}$ As one of the first laws implemented by the newly-established communist state, the 1950 Marriage Law broke with tradition by terminating the practice of arranged marriages and empowering women to initiate divorce proceedings.

\footnotetext{
Hunyin Fa Jianyi Zhi'er [Domestic Violence Shall be Expressly Prohibited - Suggestion on Draft Marriage Law by the All China Women's Federation 2], LEGAL. DAILY, Sept. 28, 2000, cited in Yuhong Zhao, Domestic Violence in China: In Search of Legal and Social Responses, 18 UCLA PAC. BASIN L.J. 211,222 (2001) (noting that domestic violence is reported in thirty percent of Chinese families); China Amends Marriage Law - Bigamy, Domestic Violence Explicitly Banned, XINHUA NEws AGENCY, Apr. 11, 2002, available at infoweb@newsbank.com. See also MINZHU YU FAZHI [DEMOCRACY \& LEGAL SYSTEM] (Feb. 1, 2002) (summarizing a special conference on combating domestic violence against women held in Beijing from November 9 to 10, 2001); Li Xiaohua, Family Violence and the Legal Guarantee and Consummation of Our Women's Human Rights, 5 HUBEI FAXUE 1-11 (1995).

44. Li Xiaohua, supra note 43.

45. In 1996, the number of divorces hit 1.13 million, compared to 389,000 in 1980. Chinese Women Lose Out in Divorce Under Current Laws, AGENCE FRANCE-PRESS, Oct. 31, 1997.

46. See generally NeIl Diamant, ReVolutionizING THE FAMILY: POlitics, LOVE AND DIVORCE IN URBan AND RuRal China (2000); Janice A. Lee, Family Law of the Two Chinas: A Comparative Look at the Rights of Married Women in the People's Republic of China and the Republic of China, 5 CARDOZO J. INT'L \& COMP. L. 217 (1997).

47. See Tai Yen-Hui, Divorce in Traditional Chinese Law, in CHINESE FAMILY LAW AND SOCIAL Change: In Historical and Comparative Perspective 75, 83 (David C. Buxbaum ed., 1978) [hereinafter CHINESE FAMILY LAW].

48. The 1950 Marriage Law was actually based on the 1931 Regulations (later promulgated as the Marriage Law of 1934), which were enacted in all communist-established areas. Marinus J. Meijer, Marriage Law and Policy in the People's Republic of China, in CHINESE FAMILY LAW, supra note 47, at 440; see also DIAMANT supra note 46; MARRIAGE AND INEQUALITY IN CHINESE SOCIETY (Rubie Watson \& Patricia B. Ebrey eds., 1991).
} 
In the process, the state replaced the family as the decision-maker, and reformulated the purpose of marriage in distinctly socialist terms, thereby impacting the rationales acceptable for initiating divorce. The 1950 Marriage Law granted some freedom to women from abusive marriages but primarily enabled them to take on the new status of socialist citizens. Thus, in every divorce decision during this era, one finds the class status of the person concerned listed behind their names. ${ }^{49}$ Article 8 of the 1950 Marriage Law even stated the purpose of the law to be that spouses would form a family in the service of the "new society". ${ }^{50}$ During this period, divorces based on anti-feudal reasons were likely to be granted, while divorces not related to feudal concerns were usually mediated and denied. ${ }^{51}$

The nascent institutional and social sanction of divorce, however, proved short lived. The practice of granting divorces flourished only from 1950 to late 1953 , and subsequently remained dormant until at least $1979 .{ }^{52}$ After the promulgation of a new constitution in 1954, it was believed that divorces were no longer socially necessary, as it was assumed that all feudal marriages had been terminated and that new marriage contracts were consensual. ${ }^{53}$ Furthermore, the period of the Cultural Revolution (1966-1976) ${ }^{54}$ represented a period of more conservative sexual mores, in which "careful" divorces and marriages, and "proper" family relations took center stage. 55

Divorces were seen as failures in the socialist project and thus discouraged. Beginning in the early period of PRC history, the work unit displaced the family, much as loyalty to nation and state was placed above allegiance to family, and ideas about nationalism and nation-building replaced family authority and interests. ${ }^{56}$ Marriage and divorce became very much politicized as "the state tried to use new family regulations and other incentives to mold a new sort of citizen and the relationship between the family and the state."57

49. Meijer, supra note 48 , at $448-49$.

50. See 1950 Marriage Law of the People's Republic of China, art. 8, reprinted in CHINESE FAMILY LAW, supra note 47 , at 479 .

51. Meijer, supra note 48 , at 465 . Ha Jin's novel, Waiting, is an excellent depiction of conflicted lovers stranded by the new Chinese legal system that substantively provides for the freedom of divorce, but procedurally prohibits it through its layers of bureaucratic mediation.

52. Meijer, supra note 48 , at 465 .

53. Indeed, while the 1950-1953 period saw the Communist party's campaign to enforce the 1950 Marriage Law, such campaigns ceased between 1954 and 1966. See DIAMANT, supra note 46, at 178.

54. For a good discussion of the legal system during the Cultural Revolution, șee SHAO-CHUAN LENG \& HungdaH CHIU, CRIMINAL JUSTICE IN POST-MAO CHINA 7, 38 (1985).

55. See DIAMANT, supra note 46 , at 280 . According to Diamant, divorce was not seen as an exercise in rights guaranteed by the Marriage Law, but instead as a manifestation of promiscuity and unethical behavior unbefitting of a true communist. Id. at 290 .

56. The unit of "family" must now fulfill its obligations toward the "Big Family"; that is, society. Meijer, supra note 48 , at 476 . For a discussion of the role of the work units [danwei] in providing all necessary social benefits to its workers, see Williams \& Woo, supra note 23; Barry Naughton, Danwei: The Economic Foundation of a Unique Institution, in DANWEI: THE CHANGING CHINESE WORKPLACE IN Historical ANd COMPARATIVe PERSPECTIVE 169-71 (Lu Xiaobo \& Elizabeth J. Perty eds., 1997).

57. DIAMANT, supra note 46 , at 17. 
People were even instructed to consider the broader political implications of their decisions regarding marriage and the family. ${ }^{58}$ Divorce was not a decision to be based on one's personal and private individual happiness. Instead, divorce needed to advance the greater goals of the socialist collective, and be considered within the broader context of existing political campaigns.

Thus, despite its initial liberating effect for women, the 1950 Marriage Law subsequently subjected marriage and divorce to political interpretations, providing divorce only when there was a "proper" reason. 59 The All China Women's Federation, foresake its former role as an advocate for residents seeking assistance with family disputes, to give high priority to producing ideology and propaganda. ${ }^{60}$ Women, more so among urban elites than the rural population, came to believe that divorces were more damaging to their interests than remaining married, except when they needed a political divorce from a spouse who was deemed to be counterrevolutionary. ${ }^{61}$

Divorce was further discouraged by a general decrease in access to legal institutions as a means of settling disputes. During the years of the Cultural Revolution (1966-1976), the state rejected formal legality and dismantled all legal apparata. Between 1954 and 1979, few women in socialist China utilized any formal legal process, including legal divorce. ${ }^{62}$ Divorce rates remained quite low, and divorces were usually mutually agreed upon, and then granted by the local marriage registration office under the Bureau of Civil Affairs. ${ }^{63}$ "Ordinary" disputes, including contested divorces, were exhaustively mediated by work units, the Women's Federation, or neighborhood residents committees. ${ }^{64}$

The state approach to divorce altered once again, however, with the end of the Cultural Revolution, which marked the beginning of a period of economic and legal reform. In 1978, along with the development of a market-oriented

\footnotetext{
58. Id.

59. While Article 17 of the 1950 Marriage Act provided for a divorce when both parties "desired it," the reality was that contested divorces were sought and granted based on "proper" reasons, which fluctuated with official campaigns and rhetoric, ranging from feudal considerations in the early 1950 s to "proper" sexual mores in the Cultural Revolution. Thus, while the 1950 Marriage Law made it easier for women to challenge local norms and customs, women's individual agency still had to meet the dictates of the state. DIAMANT, supra note 46 , at 314.

60. Id. at 213. For further discussion of these points, see generally LEGAL COMMITTEE OF THE Central PEople's Government, Hunyinfa JI QI Youguan Wenjian [The Marriage LaW and RELATED DOCUMENTS] (Beijing, 1950); KAY ANN JOHNSON, WOMEN, FAMILY AND THE PEASANT REvolution IN CHINA 147 (1983).

61. JOHNSON, supra note 60, at 147; Emily Honig \& Gail Hershatter, PERSONAL VOICES: CHINESE WOMEN IN THE 1980S 206-07 (1988).

62. DIAMANT, supra note 47 , at 216 .

63. In 1950, there were 993,000 divorces granted. In 1953, the year of the greatest movement, there were 1.1 million. The figure for 1952 is missing, but it is estimated that about one-million divorces were granted that year. Over the following years, the figure declines: In 1954, there were 710,000 divorces; in 1955, there were 610,000 ; in 1956, there were just 510,000. Meijer, supra note 48, at 465, citing JEN-MIN JIH-PAO (Peking), Apr. 13, 1957; and Ku Chou, On the Principles Followed in Matters of Divorce Since the Promulgation of the Marriage Law, in CHENG-FA YEN-CHIU 5 (1956).

64. DIAMANT, supra note 46 , at 206.
} 
economy, China re-instituted the legal system that had been dismantled during the Cultural Revolution. ${ }^{65}$ The 1980 Marriage Law was one of the first wave of non-economic laws to be implemented during this reform. ${ }^{66}$ It provided for divorce upon a showing that "ganqing puolie" "[emotions or mutual affections were broken]". ${ }^{67}$ This standard for divorce in theory enabled parties to seek a divorce without a showing of any social or political misconduct, and more pointedly, focused the granting of divorce on the deteriorating relationship between the individual parties themselves, instead of the relationship between the individual and the state.

In practice, however, petitions for divorce on the grounds of "broken emotions" encountered conceptual difficulties that hindered women's abilities to initiate divorce under the doctrine. Finally, in 1989, the Supreme People's Court issued several guidelines, clarifying what the lower courts should consider when assessing whether the marital emotions are broken. The Supreme People's Court outlined the following considerations to be weighed: 1) the foundation of marriage - whether it was voluntarily or arranged;2) relations after the marriage; 3 ) the reason for divorce - whether there was fault on the part of the defending party; and 4) the possibility of reconciliation. ${ }^{68}$ Once the parameters of the "broken emotions" doctrine were elucidated, divorce petitions skyrocketed. The divorce rate in big cities soared from three percent in 1978 to close to twenty percent in $1995^{69}$

65. See Communique of the Third Plenary Session of the 1/th Chinese Communist Party Central Committee, Dec. 22, 1978, reprinted in RENMIN RIBAO [PEOPLE'S DAILY], Dec. 24, 1978, at 1.

66. The first new laws established the legal and economic structure, as well as criminal law. See 4 LEG. AFFAIRS COMM'N OF THE STANDING COMM. OF THE NAT'L PEOPLE'S CONG. OF THE PEOPLE'S REPUBLIC OF CHINA, THE LAWS OF THE PEOPLE'S REPUBLIC OF CHINA (1979-1982) (1987) [hereinafter LEG. AFFAIRS COMM'N].

67. Martiage Law (1980), art. 25, reprinted in THE LAWS OF THE PEOPLE'S REPUBLIC OF CHINA (1979-1982), supra note 66, at 187. Although "emotions or mutual affections were broken" is a more complete translation of the Chinese phrase "ganqing puolie", I hereinafter use the shorter form "emotions were broken" for simplicity.

In the debates surrounding the 2001 amended Marriage Law, there was some discussion about changing the "breakdown of emotions" standard to a "breakdown of the marital relationship" standard. The argument for this change was that the focus on emotions emphasized the feelings of the spouses and downplayed broader societal responsibilities. Those opposed to the proposed change sought to preserve the "breakdown of emotions" language to reaffirm the primacy of free will in marriage and divorce. For a discussion of such debates, see generally, William P. Alford \& Shen Yuanyuan, Have You Eaten? Have You Divorced? Debating the Meaning of Freedom in Marriage In China, in IDEAS OF FREEDOM IN THE CHINESE WORLD (W. Kirby ed., forthcoming 2003).

68. See Supreme People's Court Directive to Lower Courts on How To Determine When "Emotions Are Broken" (Supreme People's Court, 1989), SI FA JiE SHI QUAN JI [CompIlation of JUDICIAL INTERPRETATIONS] 1086-87 (1989). The directive also identified fourteen different situations in which a breakdown in marital relations might be said to have occurred.

69. Liu Yinglang, Experts Push for Amendments to Marriage Law, CHINA DAILY, Apr. 26, 1997. 


\section{B. Social Reform and Its Effects on the Lives of Women}

On paper, the laws relating to family and marriage appear favorable to Chinese women, although their flawed implementation compromises their effectiveness. Both the Women's Rights Law and the Marriage Law guarantee the freedom to marry and divorce. ${ }^{70}$ In a divorce, these laws specify that special consideration should be given to women and children in the division of property and housing. ${ }^{71}$ For example, Article 31 of the Marriage Law stipulates that the division of the couple's shared property should be handled through consultation, with the court making judgments on a case-by-case basis, while "giving special care to the wife and children's interests."72 The 1980 and 2001 Marriage Laws even prohibit "the husband from filing for divorce during the wife's pregnancy or within a year of delivery."73

Similarly, the Women's Rights Law stipulates that "women have exactly the same rights as their spouses to occupy, use, benefit from, and dispose of all shared property, whatever their income."74 This legal protection is especially necessary for women who, upon marriage, face discrimination in the distribution of valuable housing and village land rights. Nevertheless, divorced women continue to be left without property or housing.

In theory, the divorce process itself is relatively simple, but in actuality, the divorce process reflects the changing view that divorce is both a community matter and a private matter between private individuals. There are two methods for obtaining divorce in China, the xieyi [agreement] system and the more formal court system. The degree to which each is availed of by divorce petitioners illustrates the changing perceptions of divorce and the legal system, since each method provides its own perceived advantages and disadvantages.

The xieyi system can be quicker and easier for less-complicated divorces; however, many couples shy away from the xieyi system because it requires tat they hand over their personal problems to their work units and other local organizations involved in mediation. Under the xieyi system, the parties, if they both agree, can simply file for a divorce by seeking permission from the marriage registration office of the Bureau of Civil Affairs, located at their place of residence. $^{75}$ To commence the xieyi process, the petitioning couple simply

70. Law of the People's Republic of China on the Protection of Women's Rights and Interests, art. 41 (1992) [hereinafter Women's Rights Law], reprinted in LEG. AFFAIRS COMM'N, supra note 66; Marriage Law (1980), art. 24, reprinted in THE LAWS OF THE PEOPLE'S REPUBLIC OF CHINA (19791982), supra note 66.

71. Women's Rights Law, art. 44, reprinted in LEG. AFFAIRS COMM'N, supra note 66.

72. Marriage Law (1980), art.31, reprinted in THE LAWS OF THE PEOPLE'S REPUBLIC OF CHINA (1979-1982), supra note 66.

73. Marriage Law (1980), art. 27, reprinted in THE LAwS OF THE PEOPLE'S REPUBLIC OF CHNA (1979-1982), supra note 66.

74. The Women's Rights Law, art 43 reprinted in LEG. AFFAIRS COMM'N, supra note 66.

75. Marriage Law (1980), art. 24, reprinted in THE LAWS OF THE PEOPLE'S REPUBLIC OF CHINA (1979-1982), supra note 66. 
bring their request to the marriage registration office along with their identification, residence card, an introduction letter from their work unit or residence committee, and their marriage certificate. ${ }^{76}$ The registration office must give an answer within a month, but will first conduct informal mediation, counseling, and/or education for the petitioning couple. ${ }^{77}$ If reconciliation after mediation is unlikely, a divorce will be granted. Until recently, most couples preferred the xieyi system over court litigation when seeking a divorce.

Couples increasingly have been turning to the courts as an alternative to the xieyi system to divorce, to protect their privacy by avoiding excessive mediation and intrusive involvement of community organizations. ${ }^{78}$ Even in the courts, however, divorce petitions must first be mediated under court authorities, and sometimes with the involvement of relevant units, such as the parties' work units, labor unions, or women's federation. ${ }^{79}$ In theory, this mediation step is voluntary. ${ }^{80}$ During mediation, courts are to investigate the case and try to reconcile the parties before making a judicial determination. ${ }^{81}$ If reconciliation is not possible, the court then proceeds to rule on the divorce petition, including ruling on the division of property between the parties. ${ }^{82}$ Parties dissatisfied with the court judgment may appeal to a court of the next level within fifteen days. ${ }^{83}$

These processes for divorce remain unchanged under the 2001 amendments to China's Marriage Law. ${ }^{84}$ However, as will be discussed later, the newly amended Marriage Law did attempt to address some of the problems faced by women as individual litigants in contested divorces. ${ }^{85}$ It clarified the

76. Regulation of the Administration of Marriage Registration (1985), art. 14, available at http://www.qis.net/\%7Echinalaw/prclaw45.htm (last visited May 3, 2003). This regulation was approved by the State Council on December 31, 1985, promulgated by the Civil Affairs Ministry on March 15, 1986, and amended in February, 1994. The requirement of a letter from the work unit or residence committee was apparently enacted over seventeen years ago in an effort to crack down on fraudulent divorces. Recent discussions to revise this regulation include a proposal to eliminate this requirement to give more privacy to the parties. Zeng Min. Privacy Key in Marriage Rule Change, China Daily, May 23, 2001.

77. Marriage Law (1980), art. 16, reprinted in THE LAWS OF THE PEOPLE'S REPUBLIC OF CHINA (1979-1982), supra note 66; see also LI HUN FA LU ZI XUN [LEGAL INQUIRIES ABOUT DIVORCE LAW] 10 (Wu Yuan Kuo, et al. eds., 1997).

78. Marriage Law (1980), art. 25, reprinted in THE LAWS OF THE PEOPLE'S REPUBLIC OF CHINA (1979-1982), supra note 66. Divorce filings with the court increased by $14.9 \%$ from 1997 to 2001 . Report of the Supreme People's Court to the 15th Communist Party Congress, RENMIN FAYUAN BAO [PEOPLE'S COURT NEWS], Nov. 8, 2002.

79. Id.

80. LEGAL INQUIRIES ABOUT DIVORCE LAW, supra note 77 , at 14.

81. Id.

82. Marriage Law (1980), art. 25, reprinted in THE LAWS OF THE PEOPLE'S REPUBLIC OF CHINA (1979-1982), supra note 66 .

83. LEgAL INQUIRIES ABOUT DIVORCE LAW, supra note 77, at 15.

84. See Marriage Law of the People's Republic of China (2001), arts. 31-35, available at www.isolaw.com./jsp;law/LAW-Chapters.jsp?CatID $=277 \&$ LangID $=0 \&$ StatutesID.

85. See Marriage Law of the People's Republic of China (2001), art. 32 (codifying judicial interpretations of "emotions are broken"); arts. 43-45 (recognizing domestic violence); arts. 17-19, 39 
grounds for divorce, determined what constitutes joint property, and identified parental custody and visitation rights. It also brought back community norms of fault by punishing at-fault parties in divorce and providing victims with the right to sue for compensation and the division of property.

\section{THE Voices of CHINESE LiTIGANTS}

From 1979 to 1989 , the rate of Chinese divorces more than doubled, with urban areas experiencing an even more dramatic increase in divorce rates. ${ }^{86}$ The divorce rate continued to rise between 1991 and 1995 in China's major cities. According to Chinese social scientist $\mathrm{Xu}$ Anqi, a leading expert on Chinese marriage and divorce, the divorce rate rose in Shanghai from $17.7 \%$ to $28 \%$; in Beijing from $16.6 \%$ to $23.8 \%$; and in Tianjin from $9 \%$ to $17.3 \% .^{87}$ In the most recent years for which survey data is available, 1997 through 2001, the number of divorce cases in the Chinese courts increased by $14.2 \%$ from the previous five years. ${ }^{88}$

As discussed earlier, divorces are increasingly being litigated in the courts rather than being resolved administratively and informally, and private litigants are going to court in growing numbers. For example, between 1997 and 2001, civil litigation increased by $37.3 \%$ from the previous five-year period, with housing, divorce, family, and debt cases constituting the largest categories of cases on the civil docket. ${ }^{89}$

\section{A. Ground-level Study of Divorce in China}

Previously-cited statistical and other large-scale research endeavors highlight the profound changes currently occurring within the Chinese legal system. But how are individual women experiencing these transformations? In

(clarifying property rights); and an. 47 (punishing at-fault parties for concealing marital property), available at www.isolaw.com./jsp;law/LAW-Chapters.jsp?CatID=277\&LangID=0\&StatutesID.

86. In Shanghai, the divorce rate grew more than fivefold; in Beijing and Tianjin, it grew more than threefold. Xu Anqui, The Marriage Trends in Our Cities, SOC. STUD. 3, $41-45$ (1991).

87. In general, urban divorce rates are much higher than those in rural areas. Even though the rate of increase in divorce was quite high in the 1980 s, the relative rate of divorce in world terms remained fairly low. It was not until the late 1980 s that the relative rate started to take off, with the Muslim areas of Xinjiang province producing rates that are almost as high as those in the United States. Interview by Christina Gilmartin with Xu Anqi, Research Fellow, Shanghai Academy of Social Sciences, Shanghai, China (Dec. 17, 1996) (notes on file with Christina Gilmartin). The national divorce rate was 19.4 percent in 1997. See also China Takes a Look at Divorce, ECONOMIST, Oct. 31, 1998, at 46. (finding that in 1992, the national divorce rate reached 8.7\%, and in urban areas such as Beijing, it was already as high as 17.7\%); Tony Walker, Chinese Men Embrace Divorce, WORLD PRESS REV. 40, 48 (Oct. 1993); Liu Yinglang, Experts Push for Amendments to Marriage Law, CHINA DAILY, Apr. 26, 1997.

88. Five-Year Work Report of the Supreme People's Court to the Fifteenth Party Congress (on file with author) [hereinafter Five-Year Work Report], RENMIN FAYUAN BAO [PEOPLE'S COURT NEWS], supra note 78 .

89. Id. 
1998, this author and historian Christina Gilmartin went to Shanghai to explore the reality behind these statistics from the perspective of several disciplines: history, women's studies, and law. ${ }^{90}$ Different kinds of data were collected using a variety of research approaches, including documentary research, ethnography, interviews, and case studies. We believe that a combination of methods paints a more complete picture of the status of women in the divorce process in contemporary China. ${ }^{91}$

We interviewed twenty-nine divorce litigants from different areas of Shanghai and different sectors of society. We chose to conduct qualitative interviews because we believed that for a topic as intimate as marriage and divorce, detailed interviews would yield insights that could not be gained by other means. Each of our interviews took approximately three hours. ${ }^{92}$

Of our twenty-nine interviewees, twenty were women and nine were men. We included male as well as female divorcées for a more complete picture. The interviewees were drawn from referrals as well as from visits to the numerous clubs for divorcées that are now springing up all over Shanghai. ${ }^{93}$ Our interviewees ranged in age from twenty-nine to sixty-four years old. Their lengths of marriages ranged from less than one year to thirty-five years. All of the interviewees had received some formal education. Nineteen of them had completed at least middle to high school and/or vocational training, while ten of the interviewees were university graduates. Six of the interviewees obtained their divorces through the informal xieyi system, and twenty-two through the more formal court process.

In one case, we were able to interview all parties involved in the divorce proceeding, including the litigants, the judge, and the lawyer. ${ }^{94}$ In another case, we were able to speak with the defendant and his lawyer, and received access to the entire case file. ${ }^{95}$ To supplement our interview data, we also interviewed court officials, lawyers, and administrators from the Bureau of Civil Affairs, as well as Chinese legal scholars in the area of family law. Taken together, the data provide insights regarding two critical thematic areas - the state of divorces and family formation in urban China, and the legal process facing female litigants in urban China today.

90. This author is a legal specialist who has written primarily about the Chinese legal system, while Christina Gilmartin has written extensively on gender and politics in twentieth-century China.

91. See SHULAMIT RENHARZ, FEMINISTS METHODS IN SOCIAL RESEARCH 46 (1992).

92. See interviews, supra note 1.

93. For an interesting article on these singles clubs, see Walker, supra note 87, at 48.

94. See interview with S-24 in Shanghai, China (June 1, 1998); interview with Chang Ning District Court judge, in China (June 1, 1998).

95. See interview with S-13 in Shanghai, China (May 22, 1998); interview with S-13's lawyer in Shanhai, China (May 22, 1998); see also infra section VI A (examining S-13's divorce in detail). 


\section{B. The Who, What, How and Why of Urban Chinese Divorce}

Who is petitioning for a divorce in the courts? In our interview group, women were plaintiffs in twenty cases and men were plaintiffs in nine cases. This is consistent with national statistics, as well as Shanghai's own statistics, which reveal that women are usually the initiators of divorce petitions. ${ }^{96}$ One court official we interviewed estimated that female plaintiffs in divorce cases constitute seventy percent of the divorce cases filed in Shanghai. ${ }^{97}$ In Zha Bei District Court alone, our sources estimated that divorce petitions constituted more than half of the caseload, with female plaintiffs in ninety percent of the cases. $^{98}$ Nationally, according to the statistics of the Supreme People's Court, women were the petitioners in nearly seventy percent of the divorce cases tried by the civil courts since $19800^{99}$ Interestingly, then, women are taking the initiative in the vast majority of the divorce cases filed in China.

This does not necessarily mean, however, that women wish to divorce more than men. According to our interviewees, some women initiate divorce because they do not want to be perceived as "victims" or they think it would be in their best interest to take proactive steps. According to one woman, initiating a divorce was a way to take charge of the situation, and she expressed relief at taking herself out of a bad marriage and starting anew. ${ }^{100}$ In this most private of all issues, Chinese women, at least in urban areas such as Shanghai, are stepping forward to claim their legal right to marital freedom.

\section{The Effects of Education on Chinese Women's Decisions to Divorce}

Modernization theories generally posit that education and economic development necessarily lead to greater assertion of rights. ${ }^{101}$ These theories assume that people with less education might be less inclined to assert their rights, seek the assistance of a lawyer, or otherwise use formal court processes. While not randomly chosen or statistically significant, all of the interviewees in our study had at least a middle school or above education. ${ }^{102}$ Perhaps some minimal form of education may be necessary before one feels empowered to assert one's rights sufficiently.

96. YANG DAWEN \& GUO JianMEI, THEORY AND PRACTICE OF PROTECTION OF WOMEN'S RightS AND INTERESTS N CONTEMPORARY CHINA 522 (2000).

97. Interview with Zha Bei District Court judges (May 15, 1998).

98. $I d$.

99. YANG DAWEN \& GUO JIANMEI, supra note 96, at 522; see also DIAMANT, supra note 46.

100. Interview with S-2 in Shanghai, China (May 13, 1998).

101. See EDWARD SHORTER, THE MAKING OF THE MODERN FAMILY 214-15 (1975) (positing that modernization loosens community ties and frees people to pursue their own options to become the "individuals" within the state).

102. See interviews, supra note 1 . 
At the same time, conversations with our interviewees allow us to hypothesize that too much education may work in the reverse, at least in Shanghai. Though one might expect intellectuals ${ }^{103}$ to be more aware of their rights and thus more active in bringing suit, this may not be true. Intellectuals may feel more bound by traditional precepts and more hesitant to resort to the "uncivil" conduct of litigation, while workers may be more inclined to use lawyers and the formal legal process because they feel powerless and need the court for protection. ${ }^{104}$ At least two of the ten university-educated interviewees expressed the belief that it was more "civilized" to settle the matter privately, quietly, and without controversy. ${ }^{105}$ Since courts can provide more anonymity than xieyi divorces, these educated litigants would go to court, but would not "fight" over property or other issues. One university-educated litigant even expressed the view that lawyer involvement represents a failure of sorts. ${ }^{106}$

\section{Women's Financial Independence is Linked with the Decision to Divorce}

Financial independence may prove a significant factor in Chinese women's decisions to bring suit. Many divorces are obtained by women of working age. Of the divorce litigants we interviewed, female initiators of divorce ranged in age from twenty-nine to forty-eight. Members of the Jiading district of Shanghai women's federation estimated that the bulk of divorce litigants ranged in age from twenty to forty. ${ }^{107}$ As Professor Li Weisha notes, litigants tend to be those who "have their own income and are able to lead an independent life. [T] hese women are imperceptibly influenced every day by traditional culture, including traditional ideas on marriage ... [and] they show a strong and nontraditional inclination for self-determination." ${ }^{108}$ Market reforms and the resultant migratory trends have led to a limited measure of financial autonomy and freedom for Chinese women, which has made it possible for some to "buy out" of unhappy marriages. ${ }^{109}$

103. I define "intellectuals" to be people with at least a university education.

104. See DIAMANT, supra note 46 , at 330 (describing interviews with lawyers and Women's Federation officials in Shanghai and Nanjing in 1994).

105. Interview with S-5 in Shanghai, China (May 13, 1998); interview with S-28 in Shanghai, China (June 4, 1998).

106. Interview with S-5, supra note 105 .

107. Interview with four members of the Jiading Women's Federation in Shanghai, China (May 13, 1998).

108. Li Weisha, Analysis of Female Plaintiffs in Divorce Cases, CHINESE SOC. \& ANTHROPOLOGY $84-93$ (1989).

109. DAVN, supra note 15. 


\section{E. Interviewees' Reasons for Divorce}

In today's China, the reasons people choose to divorce show that expectations about love, marriage, and individual self-fulfillment appear increasingly important. According to national studies, the main grounds for divorce include bigamy, adultery, addiction to drinking and gambling, and long-time working abroad. ${ }^{110}$ These grounds present failures in personal relationships, rather than political ones.

Our interviewees offer a more close-up look at the reasons people seek divorce. We found that of the twenty petitions brought by women, seven explicitly cited domestic violence and two cited abandonment as motivations for pursuing divorce. The rest pointed to reasons of incompatibility [xingge buhe], or more frequently, extramarital affairs.

With increasing economic freedom and the withdrawal of the Chinese state from people's private lives, China is seeing a rise in reports of extramarital affairs. This is reflected in the changing terminology from "meddling in marriages" to "the third party" to "love outside the marriage." "111 In one urban district, the Jiading District of Shanghai, members of the Jiading Women's Federation that we interviewed said the divorce rate in 1997 exceeded the marriage rate. ${ }^{112}$ They also believed extramarital affairs motivated divorce in over half of these cases. ${ }^{113}$

While reports of extramarital affairs have grown, so, too, have reports of family violence. According to a study by the All China Women's Federation, domestic violence may be a factor in thirty percent of Chinese families, and fifty to sixty percent of all divorces. ${ }^{114}$ Domestic violence, however, was not the major factor for the divorce litigants we interviewed - only one factor of many. This may be because domestic violence is still viewed as a problem that requires education, not divorce.

There is an increasing recognition that personality and emotional wellbeing can be key reasons for divorce. Today, marriage for free love is

110. Li Xiaohua, supra note 43.

111. Yang Gang, An Assessment of Using Law to Punish 'Third Party' Provision, MrN SHaNG FAXUE [CIVIL/COMMERCIAL JURISPRUDENCE] 92-94 (Dec. 2000).

112. Interviews with Jiading Women's Federation, supra note 107.

113. Id. A survey conducted by the Yangpu District civil affairs bureau, meanwhile, found that thirty-six percent of the respondents cited incompatibility and twenty-two percent cited extramarital affairs as the cause of divorce. Drug addiction and excessive gambling or dancing were blamed for twelve percent of the failed marriages. Divorce Rate in Shanghai Up, XINHUA NEWS AGENCY, July 27, 1999, at http://www.comtexnews.com.

114. Robyn Wexler, Domestic Violence, Not Just a Family Affair, CHNA DEVELOPMENT BRIEF, at http://www.chinadevelopmentbrief.com/article.asp?art=207 (last visited April 19, 2003) (reporting that in the Yideng region of the Sichuan Province, 34.5\% of 2,720 divorces reported domestic violence); see also Weekly Viewpoints: China's Various Social Circles Accord High Attention to Marriage Law Amendments, FBIS-CHI, Oct. 28, 2000; Jiang Wandi, Development of Women's Rights in China, BEIING REV. 19-20, Nov. 15, 1993 (reporting a domestic violence rate in some rural areas as high as ninety percent); but cf. Zhao, supra note 43 , at 219 (citing a rural domestic violence rate of $31.4 \%$ ). 
overtaking arranged marriages and even "intermediary" marriages (marriage through matchmakers). In the economically-developed southeast, the proportion of marriages based on free love is higher than seventy percent, and arranged marriages no longer exist. ${ }^{115}$ In sum, reform and greater freedom have led not only to possibilities of greater chasms in relations, but also to greater expectations for what a marriage should be and a growing sense of entitlement that those expectations be met.

It is important to note, however, that while seeking a divorce is no longer difficult for Chinese urban women, the same may not be the case for Chinese women in rural areas. In underdeveloped areas, arranged marriages still comprise the majority of marriages. Chinese women in rural areas still face substantial interference with their legal rights. According to an investigation of the Wulian Court in Shangdong Province, husbands and/or relatives "interfered with" at least eighty-four cases, or $27.6 \%$, of the 308 divorce cases tried by the court. ${ }^{116}$ The methods of obstruction ranged from the threat or use of direct force, to instances of jailing, binding or holding the women in custody.

\section{Problems of Property and Housing Division for Female DivorCE LITIGANTS}

In their divorce petitions, the women we interviewed asserted not only their right to marriage and divorce, but also their equal right to marital property and child custody. Yet, despite legal protections on paper, in practice, women can suffer both financial and emotional setbacks in a divorce because they often receive the short end of property and housing divisions.

The housing problem for women in divorce is attributable to a combination of factors, including housing shortages, residual effects of the work-unit housing allocation system, and traditional virilocal patterns of residence after marriage, in which women live with or near the husband's family after marriage. Until recently, most housing was distributed by the work units, which under the rationale of avoiding double allocation, often refused to allocate housing to married women. Under this distribution system, women received fewer housing vouchers and were ineligible for newly constructed homes. ${ }^{117}$ Furthermore, as women workers were often the first to be fired and last to be hired, women also faced early retirement or unemployment. Unemployment, in turn, has meant that women were least financially able to

115. YANG DAWEN \& GUO JIANMEI, supra note 96, at 503.

116. Id. at 524.

117. Elizabeth Croll, Changing Identities of ChINESe WoMen: RHETORIC, EXPERIENCE, AND SELF-PERCEPTION IN TWENTIETH CENTURY CHINA 158 (1995); Ann Jordan, Women's Rights in the People's Republic of China: Patriarchal Wine Poured from a Socialist Bottle, 8 J. CHINESE L. 47, 72 (Spring 1994). 
have independent housing or to be affiliated with a work unit, which could provide housing.

According to a recent study on housing and divorce in the state sector, where public housing allocation is most likely to occur, husbands are 2.6 percent more likely to receive housing than wives. ${ }^{118}$ Under a system of stateallocated housing, divorces were and are an administrative nuisance, as work units cannot command additional housing units to meet the demands of a divorce. Thus, until well into the 1990s, the role of the work units in a couple's marital living situation was such that "many or most court and civil affairs offices required a letter of permission from the spouses' work unit before they would process the divorce request, even when the couple was in agreement."

Property and especially housing have often become bargaining chips in contested divorces. More than one female interviewee mentioned facing pressure to compromise and give up rightful property before the other party agreed to the divorce. ${ }^{120}$ This is problematic, as women need housing in order to enjoy freedom. As Irene Tinker observes, "To survive in this rapidly changing socioeconomic milieu, women need the security of land and house to provide income and shelter for their children, and they need the power to control who shares the house.",121

Thus, the fastest divorces are often those with minimal property and/or housing disputes. These cases are funneled through the administrative xieyi system, with the parties registering their divorce agreement with the marriage registration office of the Bureau of Civil Affairs. Some of the most difficult divorce cases deal with the division of housing, and consequently, require legal assistance and are handled in the courts. ${ }^{122}$ This includes a significant proportion of all divorces; close to thirty percent of the women who go to the Beijing University Center for Women's Law Studies and Legal Services for assistance with their divorces raise concerns related to their housing. ${ }^{123}$ Our interviewees with no housing problems received divorces quickly, with minimal assistance. ${ }^{124}$

118. Liu Donghua, An Analysis of Chinese Women's Housing Issue in Divorce: A Proposal for Residence Rights Reform 39 (1994) (unpublished manuscript, on file with author), citing Statistical Data on the Status of Modem China Women, chart 1.9.

119. William J. GoOde, World Changes in DivorCe Patterns 311 (1993).

120. See interview with S-8, supra note 2; interview with s-10 in Shanghai, China (May 19, 1998).

121. IRENE TINKER, Women's Empowerment Through Rights To House and Land, in WOMEN'S RIGHTS to HOUSE AND LAND: ChINA, LAOS, VIETNAM 9 (Irene Tinker \& Gale Summerfield eds., 1999).

122. See Wu Yuan Kuo, Li Hun fa l Zi Xun [INQuiries about the Law of Divorce] 8-10 (1997).

123. Five-Year Consulting RePort, CENTER for WOMEn's L. Stud. \& Legal Service BEIING U (on file with author) (also concluding that fifty-one percent of the divorce petitions surveyed in 1998 involved contested housing).

124. See, e.g., interview with S-14 in Shanghai, China, (May 22, 1998); interview with S-20 in Shanghai, China (May 24, 1998) 
The Supreme People's Court, the highest court in China, found it necessary in 1993 to issue the interpretation, Concerning the People's Court's Adjudication of Property Divisions in a Divorce, ${ }^{125}$ which reaffirmed women's right to property upon divorce. In 1996, it acted again in Reply Concerning Questions of the Use and Lease of Public Housing Arising in the Adjudication of Divorce Cases, protecting women's rights as leaseholders of public housing if their marriages have lasted for five or more years. ${ }^{126}$ This 1996 directive sets forth clearer guidelines to determine who can be awarded rental rights in public housing after divorce. ${ }^{127}$ It gives both divorced parties the right to lease the public housing in which the couple has lived if "one of the parties leased the public housing before marriage, and the marital nexus has lasted for five years or more,", 128 or if "one or both parties applied and acquired the right to lease the public housing after marriage." 129

The directive urges courts to consider equity when dividing common housing by requiring a living allowance or requiring both people to live in the shared home for up to two years after divorce while they arrange for other housing. ${ }^{130}$ This has proven to be a problem in instances of domestic violence, where the victim must share housing with the batterer.

The directive also urges the courts to consider the needs of women in the division of property. ${ }^{131}$ Yet, although the directive emphasizes equitable division of common housing rental rights, in reality those rights ultimately belong to the work units, which have been known to interfere with women's legal rights by avoiding the transfer of homes. ${ }^{132}$ As Ann Jordan notes, as long as housing remains a work-related benefit, the divorce provisions contained in the Marriage Law and the Women's Rights Law will be ineffective. ${ }^{133}$

The recent movement to privatize the housing market has not entirely eliminated the problem of housing for female divorcées. Despite its recent efforts in housing reforms, ${ }^{134}$ Shanghai still faces particularly acute housing

125. Concerning the People's Court's Adjudication of Property Divisions in a Divorce (Supreme People's Court, Nov. 11, 1993), reprinted in SI FA WEN JIANG JING XUAN [SELECTED COMPILATION OF LAW AND REGULATIONS] 464 (1996)

126. Reply Concerning Questions of the Use and Leasing of Public Housing Arising in the Adjudication of Divorce Cases, (Supreme People's Court, February 5, 1996.) [hereinafter Reply], reprinted in WU YUAN KUO, LI HUN FA L ZI XUN [ON DIVORCE LAW INQUIRIES] 190-93 (1997).

127. $I d$.

128. Id.

129. Id.

130. Id.

131. Id.

132. Dia Warren, Chinese Women's Housing Rights, in WOMEN'S RJGHTS TO HOUSE AND LAND: CHINA, LAOS, AND VIETNAM 137, supra note 121.

133. Jordan, supra note 117 , at 73-74.

134. Housing reform in Shanghai came in two stages. In 1980 and 1990 , two main measures were taken. The first transferred responsibility from state and local governments to businesses that invested in housing construction and offered commercial housing to the public. The second began on February 8 , 1991, under the Shanghai government's Executive Plan of Housing System Reform in Shanghai, which used a public accumulation fund paid by staff and workers in cities and work units; raised rents and gave 
shortages. ${ }^{135}$ Similarly, an investigation in the Dongchen District of Shanghai in 1997 concluded that in ten sub-districts, $61.1 \%$ of divorced women lacked housing. ${ }^{136}$ Women experiencing domestic violence confront even greater problems. No real network of women's shelters exists, although a handful of new shelters opened in the $1990 \mathrm{~s}^{137}$

\section{THE LITIGATION EXPERIENCE FOR CHINESE WOMEN}

Adjudication, as a form of social ordering, can govern and regulate the relationships people have with one another. ${ }^{138}$ Women have carved out spheres of autonomy through the adjudication process. Our interviews illuminated existing attitudes toward and experiences with the legal process itself. The following case gives a flavor of the legal process, the sensibilities of the parties involved, and the marital interests affected. The case of $\mathrm{Z}$ and $\mathrm{L}^{139}$ illustrates the difficult issues facing Chinese couples in divorce today, highlighting the interplay between domestic violence, housing pressures, and the limitations of the court process in resolving such disputes.

\section{A. The Case of $Z$ and $L$}

$\mathrm{Z}$ and $\mathrm{L}$ were middle-school classmates who married in 1983, and had a daughter the following year. In 1997, after fourteen years of marriage, $L$ filed for divorce. As grounds for the divorce, $L$ claimed domestic violence by $Z$, as well as "broken marital emotions," pursuant to the 1980 Marriage Law. In support of her petition, $\mathrm{L}$ alleged that her husband frequently beat her, even in the month after she gave birth. In 1993, L sought the assistance of her work

subsidies; rationalized housing with bonds (requiring staff and workers to buy housing construction bonds when renting public housing); and sold preferential housing, which work units must sell before renting at preferential prices. Fei Juanhong, Impacts of Shanghai Housing Reform, in WOMEN'S RIGHTS TO HOUSE AND LAND: CHINA, LAOS, VIETNAM 198-199, supra note 121.

135. Limited housing in the 1970 s to early 1980 s led to a dramatic increase of virilocal residence (women living with the husband's family), exceeding even the rates from before 1949. Since housing reform took place in the $1980 \mathrm{~s}$, the percentage of unilocal residence has risen again. Id. at 196-97.

136. While the average living space per capita in Shanghai proper grew from 3.9 square meters in 1949 to 8.5 square meters in 1996, 61,500 families in Shanghai still had an average living space per capita under 4 square meters in 1995, and many newly-married couples were in urgent need of housing. Since housing tends to be small, it is rarely practical to divide a house up into more than one smaller residence. Even the recent reform in the commodification of housing does not help women, since the rent is so high as to be prohibitive for many people. Since women eam less than men, it is more difficult for them to purchase housing. Fei Juanhong, supra note 134, at 205.

137. The New Sun Women's Marriage Stop was apparently established by a female entrepreneur in Hubei in 1995, and the Help Center for Women and Children Suffering from Domestic Violence in South China was established in Shanghai in 1996. See Zhao, supra note 43, at 248.

138. Lon L. Fuller, The Forms and Limits of Adjudication, 92 HARV. L. REV. 357 (1978).

139. $Z$ is interviewee $S-13$. We interviewed both him and his lawyer and had access to his court documents. See interviews with S-13 and his lawyer, supra note 95 . The following case study is an accurate description of his divorce experience, based on these sources. 
unit, which tried to mediate the dispute by issuing a document to the defendant directing him to refrain from abuse. The document was enclosed as evidence in the divorce petition. In the latter half of $1996, \mathrm{Z}$ developed a habit of going to saunas and, when L objected, would hit her. On May 2, 1997, L alleged that the defendant beat their fourteen-year-old daughter when she accidentally broke a rice bowl. L additionally alleged abuse on May 5 , when she claimed $\mathrm{Z}$ beat her when she was too tired to clean the house. L sought custody of her daughter, child support payments of RMB 300 yuan (approximately \$31) a month, as well as proper distribution of marital property, including the couple's apartment.

The defendant, L's husband Z, did not contest the divorce or custody of his daughter, but did contest the division of property. In his response, $Z$ challenged the distribution of the marital property and alleged that $L$ had engaged in domestic abuse of his elderly great aunt. Z's great aunt $\mathrm{Y}$ also intervened as third party to object to certain property (an air conditioner, a heater, an easy chair, a telephone, and a pager) being designated as marital property. Y maintained that she paid for these items herself, and thus they remained her property.

The divorce process began when the court telephoned $\mathrm{Z}$ at his home to notify him of the petition. $Z$ picked up the divorce petition on June 9, 1997. A day later, on June 10 , two judges spent one hour with the family cataloguing the household property. On June 18, the parties had a two-hour hearing with one judge and one secretary present. At that meeting, a representative of L's work unit testified. Relatives of both parties were also present. $Z$ brought a lawyer and his brother-in-law, and $L$ brought a representative from her work unit and a former classmate. There was some minimal effort to mediate the matter by the court. The judge simply asked if the parties agreed on the divorce and, since they did, moved quickly to discuss the division of property.

Because the parties could not agree on a property division, subsequent hearings were held on September 29, and again on November 27. The allocation of the family apartment, which was still occupied by $Z, L$, their daughter, and Z's great-aunt $Y$, proved to be a bitterly-contested issue. The apartment consisted of four rooms: one room (8.9 square meters) on the first floor, plus three rooms on the second floor: a southwest room (8.7 square meters), a middle south room (23.7 square meters), and a north room (16.4 square meters). The landing, kitchen, bathroom, and balcony were considered to be common spaces.

By the time a decision was rendered on Dec. 29, both parties had retained lawyers. Citing articles 25, 29, 30, and 31 of the Marriage Law, the district court awarded the divorce and made the following findings. The court awarded custody of the daughter to $L$ and ordered $Z$ to pay monthly child support of 300 yuan. The contested property (air conditioner, heater, easy chair, telephone and 
pager, etc.) was deemed marital property because $\mathrm{Y}$ was not able to provide receipts to prove ownership. Nevertheless, $Z$ and $L$ agreed to give the easy chair and heater to $Y$. After investigation, the district court found that the apartment had originally belonged to $Z$ 's grandmother, and that $Z$ inherited the apartment in 1993 after her death. In dividing the property, the court awarded the first-floor room (8.9 square meters) and the second-floor southwest room (8.7 square meters) to $\mathrm{L}$ and her daughter. $\mathrm{Z}$ and his mother received the middle south room (23.7 square meters) and the north room (16.4 square meters). The court then awarded the remaining property, including an eightpiece redwood furniture set, to $Z$, but ordered $Z$ to pay 20,000 yuan to $L$ in compensation.

L filed a timely appeal in which she contested the division of the apartment and furniture. $\mathrm{L}$ argued that the apartment had been unfairly divided because she and her daughter were awarded the two smallest rooms, totally 17.6 square meters, with Z's rooms totalling 23 square meters more than L's. L sought a redivision, in which the north room (16.4 square meters) and the southwest room (8.9 square meters) went to $\mathrm{L}$, and the central south room (23.7 square meters) and the southwest room ( 8.7 square meters) went to $Z$. The present division, argued L, deprived her of her legal rights and unfairly interfered with her ability to raise and educate her daughter. L also contested the award of the redwood furniture set to $Z$. She claimed this furniture set was marital property and should be divided as such.

In response, Z's lawyer (a woman) filed papers arguing that the award of the redwood furniture was fair, because the furniture was valued at 40,950 yuan and $Z$ had been ordered to give L 20,000 yuan in compensation. As for the division of housing, Z's lawyer made several arguments. First, she argued that in this situation, $Y$ 's legal interest was separate from $Z$ 's. Y, she said, was a separate family unit, and thus must be awarded housing independently of $Z$. $Z$ 's lawyer argued that the southwest room should not be considered part of the marital property, but rather Y's property, because $Y$ had lived in that room since 1934. A letter from the residence committee, a neighbor's testimony, and $Y$ 's own testimony were submitted as supporting evidence.

Second, Z's lawyer argued that $Z$ must be awarded the north room because the north and the southwest rooms were connected, forcing one to walk through the southwest room to get to the north room. Because $Y$ required constant medical attention, the lawyer argued that $Z$ must live in the room closest to $Y$ in order to care for her. Finally, $Z$ and his lawyer argued that since $L$ had been maltreating $Y$ for the past few years, it would be impractical to put her in the room next to $Y$ 's. $Z$ also argued that he should be allowed to remain in the southwest room, since he had lived in that room since the two were married. $Z$ 's final argument asserted that if $\mathrm{L}$ argued that the property division would 
harm her ability to raise her daughter, the court should award custody to $Z$, who would not seek any child support from $\mathrm{L}$.

Upon appeal, the Shanghai intermediate court re-investigated the case. Hearings were held on April 15, 1998, and on the following May 13. In both sessions, the judge attempted mediation. No new evidence was submitted. We did not witness the conclusion of these hearings.

At the time of our interview, $Z$ was quite frustrated with the court and the length of the divorce process. He resented having to pay a 50-yuan initial court filing fee and an additional 1450 yuan because the amount of the contested property was high, as well as 800 yuan for the investigation. (The parties would not have to split the fees until the end of the case). He had also expended over 2,000 yuan in lawyer fees to date. While the case was pending, $\mathrm{L}$ did not allow him to see his daughter, and when he complained to court, the judge said, "nothing could be done." At the time of the interviews, no decision was in sight. When asked to score the court's work on a scale of one to ten, $Z$ gave the court a score of five.

\section{B. Observations from the Case of $Z$ and $L$ and Other Interviewees}

Several observations can be made from this case, which are also supported by the interview and other data. In this case, lengthy and complicated procedures did not seem to deter the parties, contrary to accepted notions that Confucian ideology shuns litigation. The litigation in this case also reflects the changes in the legal system itself. While the case began as a community matter involving mediation and the involvement of the work units, it was subsequently filed in court, where it became more of a private matter between individuals.

In the courts, the work units retained influence, but their role in the process was substantially reduced. The work units primarily served a testamentary function, in which they were called upon to give evidence to a final arbitor, in this case the court itself, rather than acting as the primary problem solvers themselves, as they had in the past. This finding was consistent with the other interviews. In a few cases interviewees expressly mentioned that the work unit had mediated prior to the filing of the divorce petition in court. ${ }^{140}$ In at least

140. See, e.g., interview with S-21 in Shanghai China (May 24, 1998); interview with S-22 in Shanghai, China (May 28, 1998); interview with S-26 in Shanghai, China S-26 (Jun. 2, 1998). Both S21 and S-22 had marital problems dating from the late 1980 s and mentioned mediation by the work units prior to filing of claims. Two interviewees, S-19 and S-29, mentioned work-unit participation in mediation during the court process. Interview with S-19 in Shanghai, China (May 24, 1998); interview with S-29 in Shanghai, China (June 4, 1998). 
one case, the court adjudicated the divorce after a brief one-hour hearing with the parties alone. ${ }^{141}$ The process was quick and private.

These examples suggest that at least some individuals are experiencing increased liberation from work-unit control and are instead relying on outside institutions, such as the courts, for dispute resolution. In fact, several litigants mentioned that they preferred to go to court because it could be simpler without the involvement of the work unit. ${ }^{142}$ (The court system is technically free of the xieyi divorce requirement that parties petitioning for a divorce submit a letter from their work units or residence committees, although in reality the courts consult the work units regarding housing and other issues.) ${ }^{143}$

Many of our interviewees also stated that divorce should take place between individuals, not collectives. Yet in our interviews, even where the roles of the work units and residence committees were reduced, they were still important. Collective organizations were often called in to give evidence, particularly with reference to the issue of housing, ${ }^{144}$ and courts consider their credibility high. ${ }^{145}$ It may be that the role of mass organizations is evolving from a role of resolving disputes into one of acting as advocates or witnesses in the court system.

In the $\mathrm{Z} / \mathrm{L}$ case, the elderly aunt $\mathrm{Y}^{\prime}$ 's interest was ultimately argued as a separate interest apart from those of the husband and wife. This divorce reflects the increasingly accepted view of the family in China as consisting of a "nuclear family," with the husband and wife as the core. Indeed, the average size of the Chinese family decreased from 4.51 persons per family in 1982 to 3.63 in 1998 , with over $76.54 \%$ of the families in China comprised of four or fewer persons. ${ }^{146}$ Bi-generational families (usually parents with unmarried children) have replaced multi-generational families. ${ }^{147}$ In the courts, and in divorce litigation, the relevant interests are those of the individual litigants.

While lawyers represented $Z$ and $L$, less than half the litigans we interviewed used lawyers for the divorce process. Four of the nine men used

141. Interview with S-24 in Shanghai, China (June 1, 1998); interview with S-25 in Shanghai, China (June 25, 1998).

142. See, e.g., interview with S-23 in Shanghai, China (May 31, 1998); interview with S-28 in Shanghai, China (June 4, 1998).

143. See supra notes $77-82$ and accompanying text.

144. See, e.g., interview with S-10, supra note 120. The work units of both parties appeared in court to present evidence. The female plaintiff in this case complained that the court process was too troublesome and thought xieyi would have been simpler. See also interview with S-13 in Shanghai, China (May 22, 1998).

145. Interviews with lawyers and women's federation members suggest that when women's federations get involved, it is often to the benefit of the women. See interview with members of the Jiading Women's Federation, supra note 107; interview with Zha Bei District Court judges, supra note 97.

146. Chen Wei, ZhongGuo Hun Yin Jia Ting Fa li Fa Yanju [ANalysis of the PROMUlgation OF ChINA'S MARRIAGE AND FaMILY Law] 7 (2000). Bi-generational families constitute $62.83 \%$ of the families in China today.

147. Id. 
lawyers, ${ }^{148}$ while seven of the twenty women had legal representation. ${ }^{149}$ Unsurprisingly, those involved in more complicated and contested divorces sought legal assistance more frequently.

Finally, as indicated by Z's rating of the legal process at five out of ten, the level of satisfaction with the legal process by the litigants is mixed. Here, the picture is more nuanced and complex. Interviewees' comments reflected varied perceptions of the efficacy and fairness of the divorce process. Naturally, those who get what they want tend to be more satisfied with the process, while those with problems tend to be less satisfied with the courts. A husband who petitioned three times before getting a divorce was very dissatisfied with the process. ${ }^{150}$ One woman thought that her husband who was "fierce" had gotten his way, and criticized the judge as simply an administrator who "gave in" to her husband. 151 A second thought the judge was too "young" and that her "privacy was invaded" by the process. 152 One thought that husband, a cadre, had influenced the judge. ${ }^{153}$ Another thought the judge did not treat her well because she was too "fashionable." 154

Perhaps more significant are the reactions to the litigation process of those with favorable outcomes. These comments by both male and female litigants have significant implications for female litigants in court. Interviewees with varying outcomes commented that their judge seemed "cold and bureaucratic,"155 or was "simply an administrator,"156 with "no understanding." 157 By contrast, those who were satisfied with their court process commented that their judge was "sympathetic"158 or "warm.",

These comments could lead to two separate, but perhaps not inconsistent, observations. First, as a whole, the comments expressing dissatisfaction relate more to the professionalism and competence of judges, rather than general dissatisfaction with going to court or viewing adjudication as a personal failure. Second, the basis of these complaints seems to be that judges are either

148. One of the men asked a friend to be his lawyer.

149. The men using lawyers were S-7, S-13, S-23, S-28; the women with lawyers were S-2, S-3, S$8, S-9, S-18, S-23$, and $S-29$. One of the women only used a lawyer in her appeal.

150. Interview with S-7 in Shanghai, China (May 18, 1998).

151. Interview with $S-9$, supra note 3 (mentioning "a judge like an administrator. . [that] always gave in to the husband.").

152. Interview with S-8, supra note 2 .

153. Interview with S-19, supra note 140 .

154. Interview with $S-15$ in Shanghai, China (May 22, 1998).

155. Interview with S-7, supra note 150 ; interview with $S-8$, supra note 2.

156. Interview with S-9, supra note 3; interview with S-3, in Shanghai, China (May 13, 1998); interview with S-12 in Shanghai, China (May 21, 1998); interview with S-17 in Shanghai, China (May 24, 1998); interview with S-1 8 in Shanghai, China (May 24, 1998).

156. Interview with $S-10$, supra note 120.

156. Interview with $S-9$, supra note 3.

157. Interview with S-16 in Shanghai, China (May 24, 1998).

158. Interview with S-3, supra note 156 ; interview with S-12, supra note 156 ; interview with S-17, supra note 156; interview with S-18 supra note 156.

159. Interview with $S-10$, supra note 120. 
unprofessional or too formal. While some complained that the judges were too young, and didn't understand, ${ }^{160}$ others complained that the judge acted "too simply," or "too quickly." ${ }^{\prime 61}$ These litigants felt that their voices or stories were not heard, and that their participation, as a result, was limited. One must ask then whether the courts and the formal process provide these litigants with a sense of personal integrity and participation in a political system.

Our interviews also suggest that litigants who know what they want or are determined to obtain a specific settlement are more likely to succeed in court. Hence, the female litigants we interviewed who were determined to divorce and who held their ground largely succeeded in obtaining divorces. ${ }^{162}$ Litigants who did not or could not hold their ground, however, had to give up property and custody in order to obtain divorces. ${ }^{163}$

Finally, a word needs to be said about formal mediation. Mediation is still a force in China, although its venues of importance are shifting from informal mass organizations to the courts. Thus, while informal mediation by residence committees and work units has declined, formal mediation in the courts continues. ${ }^{164}$ While the number of adjudicated divorces is increasing, most divorces still must first go through mediation, and the number of mediated divorces remains large.

\section{LIMITATIONS OF A MARKET BASED LEGAL SYSTEM}

Encouragingly, Chinese women are litigating in the courts, often against the odds, suggesting complex calculations on the part of female litigants and an interesting and changing role for courts in China. The litigation of divorce cases can be seen in the context of civil litigation generally. Increasingly, the Chinese state is encouraging the use of courts, which it sees as integral to a stable society and consistent with its goal of reining in local bureaucrats. In 1996, the Supreme People's Court decreed that Chinese courts should "further improve the work of trying civil cases, protect the civil rights and interests of citizens and legal persons according to the law, and promote the just, safe, civilized, and healthy development of society." 165 This is certainly a far cry from the sentiments of 1950 s, when disputes were directed away from the formal legal system and handled informally.

160. Interview with S-8, supra note 2 .

161. Interview \& court observation with S-25 in Shanghai, China (June 1, 1998).

162. See interview with S-24, supra note 141 ; interview with S-25, supra note 141 .

163. See, e.g., interview with S-5, supra note 105 ; Interview with S-8, supra note 2.

164. See LUBMAN, supra note 9, at 224.

165. Supreme People's Court Report (Delivered by Supreme People's Court President Ren Jianxin at the Fourth Session of the Eight National People's Congress, Mar. 12, 1996), cited in BBC SUMMARY OF WORLD BROADCASTS, Apr. 9, 1996, at 26. 
China recently has been experimenting with aspects of the adversarial system's focus on individual party autonomy as a supplement to its inquisitorial, civil-law-based legal system. To improve the working of courts, China is moving from its traditional priority of substance over procedure to a more concrete focus on court process. ${ }^{166}$ While the first ten years (1979-1989) of China's legal reforms saw the enactment of primarily substantive legislation, the next ten years saw greater attention being paid to the improvement of the legal process itself. ${ }^{167}$

Thus, in recent years, law enforcement has become more focused on the individual, with a reduction in state intervention and an increased reliance on the market to provide legal services and on individuals to assert their rights. Revised court procedures place increasing responsibility on individual litigants to bring and prove a case. ${ }^{168}$ Moving away from the civil-law inquisitorial tradition, Chinese law reforms specifically place the burden of presenting a case on individual litigants, rather than on the judge (and hence, the state). ${ }^{169}$ The policy slogan in the Chinese courts is now dangshiren zhuyi [litigant's choice].

\section{A. The Problem of Individual Responsibility for Rights Assertion and Gender}

Placing the responsibility for asserting their rights on individual litigants may mean the development of greater rights consciousness, but it can present special problems for those without power. Indeed, without financial resources or legal knowledge, it is difficult for litigants to navigate the judicial system, understand how to obtain proof, or even know what proof is necessary. In the context of divorce cases, this latest change may be most problematic for female litigants whose wealthy husbands attempt to hide family assets from the divorcing wife and the purvey of the court. Institutional barriers may prevent even the most knowledgeable female litigant from advancing her claim of hidden assets within the courts. Even if a female litigant procures legal assistance, she must meet a stringent, often impossible, burden of proof before the courts will act on a hidden asset claim. ${ }^{170}$ In at least one case, the burden of

166. See Five-Year Court Reform Plan (Supreme People's Court, 1999), 6 ZUI GAO RENMIN Fayuan Gongbao [Bulletin of the Supreme PeOple's Court] 193 (1999). In 1999, China took another daring step towards court reform by issuing a five-year plan. The five-year plan outlined a series of reforms to take place during the years 1999 to 2004, which ranged from reforming the process of adjudication to reorganizing the judicial personnel in adjudication. As a policy document, the fiveyear plan identified goals that ranged from the specific to the general and authorized lower courts to experiment with methods to attain them. The plan, therefore, stands as an interesting documentation of the direction of Chinese legal reforms.

167. See LUBMAN, supra note 9.

168. Supreme People's Court Report, supra note 165.

169. Five-Year Court Reform Plan, supra note 166.

170. This point is not lost on women's advocates such as Hainan Province Women's Federation Director Mou Weiping, who notes the difficulty women face 
proof on an individual spouse (even with a lawyer's assistance) to prove that the husband hid assets proved overwhelming. ${ }^{171}$ As the defendant in this divorce, the female litigant was awarded furniture (a bed and a table) and reallocated a small room for housing, but was otherwise left destitute. ${ }^{172}$

Moreover, the changing role of judges in China complicates female litigants' abilities to prevail in hidden assets claims. Previously, Chinese judges controlled the investigation, learned about the parties and the facts, and educated "wrongful parties" when necessary. Today, judges serve less as educators or counselors intent on resolving contradictions, and more as arbiters in the resolution of a dispute brought before them. ${ }^{173}$ By placing greater responsibilities on individual litigants, the Chinese legal system is relying more on the market to provide justice and less on the state to step in to alleviate power differentials between litigants. ${ }^{174}$

As a result, lawyers have complained of the lack of remedies afforded by judges. Judges are powerless to order compliance by a defendant in the enforcement of a judgment, and are sometimes unable to require a defendant to appear in court to answer a complaint. ${ }^{175}$ In some instances, some judges have taken initial steps toward judicially created remedies. For example, since the temporary right of residence provided by Chinese regulations is dependent on eight or more years of marriage and limited to two years duration, women facing divorce are still disadvantaged and face eventual homelessness. ${ }^{176}$ As noted by Liu Donghua, a lawyer for the Beijing University Center for Women's Law Studies and Legal Services, judges have created a residence right for women who are left without housing in a divorce, which although not found in the regulations, has permitted women to remain in the marital home. ${ }^{177}$

This emergent focus on the adversarial process and individual responsibility in court has meant that female litigants need lawyers more than

in documenting a husband's assets. Zhou Zhenping, China's Biggest Divorce Property Dispute Opens Hearing, XINHUA NETWORK, HAINAN BRANCH, March 25, 2003; see also interview with S-9, supra note 3.

171. Interview with S-9, supra note 3 .

172. Id.

173. See interview with S-5, supra note 105 (complaining that "judges don't explain why, they just ask questions and issue a decision."); interview with S-8, supra note 2 (describing the role of the court as limited and noting that the judge did no mediation or investigation). But see interview with S-17, supra note 155 (stating that the judge had advised the wife to ask for property, but she refused, fearing that it would slow down the divorce)

174. In interviews conducted by the author in 1998, Chinese judges express the view that their role is limited to upholding the letter of the law, rather than advising against the wisdom of a negotiated settlement. See interview with Zha Bei District Court judges, supra note 97; interview with S-8, supra note 2.

175. Interview with Zha Bei District Court judges, supra note 97; interview with Chang Ning District Court judge (Jun. 1, 1998). (1997)

176. See Wu Yuan Kuo. et.al., Li Hun Fa L Zi Xun [INQUiRIES ON THE LaW OF DivorCe] 192

177. Liu Donghua, supra note 118 , at 26 . 
ever. Disturbingly, most cases are litigated without the assistance of counsel. ${ }^{178}$ According to Chinese legal scholars, lawyers in China hesitate to take on divorce cases, viewing them as unprofitable and difficult to resolve. ${ }^{179}$ The litigants we interviewed expressed conflicting attitudes toward lawyers and the legal profession. Some of the interviewees did not believe that lawyers were of any help, ${ }^{180}$ while others reported lawyers to be of great help, particularly on issues of property division. ${ }^{181}$ Nevertheless, for the individuals currently appearing before the courts, lawyers serve as crucial intermediaries between the state and the individual. In this reform era, in which "whoever raises the issue has the burden of producing the evidence," lawyers are increasingly needed to gather evidence, build cases, and negotiate settlements. ${ }^{182}$

\section{B. China's Dearth of Lawyers and Legal Services and its Effect on Women}

As of 2000 , China boasted some 150,000 lawyers, an increase from 3,000 lawyers in 1982 - an insignificant number in comparison to a population of 1.22 billion. $^{183}$ Women constitute a fast-growing percentage of the profession, but as of 2000 , only 50,000 or so women were lawyers, comprising only $20 \%$ of the legal profession nationally, ${ }^{184}$ and $30 \%$ in Beijing. ${ }^{185}$ This is a vast improvement since 1992 , when there were only 4,512 female lawyers. ${ }^{186}$

More problematic is the maldistribution of legal services over China's vast geography and over legal specialties. Lawyers still appear in only a small percentage of civil cases in the first instance. ${ }^{187}$ Since marriage and family cases are not as profitable as commercial cases, some participants in the legal

178. In 1995, of the 4,889,353 cases filed, lawyers reportedly participated in just 863,574 . ZHONGGUO FALU NIANJIAN 1996 [LAW YEARBOOK OF CHINA 1996] 957, 975 (1996). In 1999, lawyers handled 20,173 of the 190,502 civil cases of the first instance. ZHONGGUO FALU NIANJIAN 2000 [LAW YEARBOOK OF CHINA 2000] 856, 862 (2000).

179. Interview with legal scholars at the Fudan University legal aid office (May 22, 1998); interview with legal scholars from the Shanghai City Women's Federation (May 12, 1998).

180. See, e.g., interview with S-7, supra note 120; interview with S-9, supra note 3; interview with S-28, supra note 142 .

181. See, e.g., interview with S-2, supra note 100; interview with s-3, supra note 156.

182. See, e.g., interview with S-29, supra note 140. The judges in S-29's case did not investigate and her lawyer performed minimal investigation, only speaking to her work unit.

183. William P. Alford, Tasselled Loafers for Barefoot Lawyers: Transformation and Tension in the World of Chinese Legal Workers, CHINA QUARTERLY (March 1995) 22. For contrast, see Kenneth F. Boehm \& Peter T. Flaherty, Legal Disservices Corp.: There are Better Ways to Provide Legal Aid to the Poor, 74 POL'Y REV. 17 (1995) (observing that the United States had 896,000 lawyers for its nearly 260 million people in 1995).

184. Statistics compiled by the All China Lawyer's Association, available at http://www.acla.org.cn/pg/article.php?articlelD=1929\&biglD=1\&smalD=11 (last visited February 19, 2003).

185. Id.

186. China's White Paper: The Situation of Chinese Women (BBC television broadcast, Jun. 11, 1994), originally reported by XINHUA NEWS AGENCY, Jun. 3, 1994.

187. For example, in Hubei Province, lawyers handled 20,173 of the 190,502 civil cases of the first instance. ZHONGGUO FAL NIANJIAN 2000 (2000). 
system believe the marketplace of legal services has resulted in fewer lawyers going into this area. ${ }^{188}$ Hence, even with the grow th of the number of lawyers, there remains a tremendous dearth of lawyers for female litigants in need. To make matters worse, while a sizable number of lawyers are found in urban areas such as Shanghai, lawyers are scarce commodities in rural areas. For example, while there are 3,522 full-time lawyers in the city of Shanghai alone, there are only 1,220 lawyers in the entire province of Guizhou. ${ }^{189}$ Allowing the market to determine the distribution of legal services may result in a maldistribution of justice.

\section{Reforms and Remedies}

In 1999, in order to enable access to justice, the Supreme People's Court implemented procedures to waive filing fees and other litigation costs. ${ }^{190}$ There have also been efforts to establish a nationwide legal aid system and hotline. ${ }^{191}$ However, full legal aid programs have been concentrated thus far in economically developed areas, such as Guangdong Province, leaving the rural poor still in need. ${ }^{192}$ The All China Women's Federation has attempted to alleviate this dilemma by providing counsel and advice through its legal departments. ${ }^{193}$ Additionally, embryonic legal aid centers are beginning to appear in law schools. In Beijing, the Center for Women's Law Studies and Legal Services, established in 1995 at Beijing University Law School, gave more than 3000 consultations in its first two years of operation. ${ }^{194}$ Other centers include The Center for the Protection of the Rights of the Socially

188. See interview with legal scholars at the Fudan University legal aid office, supra note 179; interview with legal scholars from the Shanghai City Women's Federation, supra note 179.

189. ZHONGGUO SIFA XING ZHENG NIANJIAN, [LAW YEARBOOK OF CHINA'S REGULATIONS] 85, 133 (2001). Shanghai even established a website to answer legal inquiries. See www.148net.com; see also China; Overcoming Rural Poverty, Joint Report of the Leading Group for Poverty Reduction, UNDP \&WORLD BANK, Feb. 23, 2000 (observing that the disparity in legal resources is also a reflection of the growing income gap between the urban elites and rural poor).

190. See Notice of the Supreme People's Court Concerning Legal Assistance in Civil Cases (1999), at http://www.chinajudge.com/fgzhchh.htm (last visited Oct. 22, 2002). (1999)

191. Benjamin Liebman, Legal Aid and Public Interest Law in China, 34 TEX. INT'L L.J. 211, 221

192. The Ministry of Justice announced plans to establish a nationwide legal aid system in 1994, and in 1996, it formally established a legal aid center to oversee the development of such programs. In 2000 , the Ministry issued a circular urging the development of legal aid at the local levels. Although the Ministry of Justice lists the development of legal aid as a central goal under its ninth five-year plan, the central government remains noncommittal as to how much funding it is willing to provide to support legal aid. See LAW YeARBOOK Of ChINA'S Regulations, supra note 189, at 47.

193. Liebman, supra note 191 , at 211.

194. FIVE-YEAR CONSUlTING REPORT, supra note 123. Since last year, the Center has concentrated its efforts on a small number of complicated and important cases with wider social ramifications, including unfair dismissal, wrongful arrest, occasioning bodily harm to rural women in the enforcement of birth control regulations, and disinheriting women upon the death of male relatives. 
Vulnerable at Wuhan University, ${ }^{195}$ and a recently-established legal aid clinic for workers at Zhongshan University in Guangzhou. ${ }^{196}$

Some limited efforts have been made to address the needs of rural women. In Qianxi county, Women's Legal Services recently opened, and in Xian, the Shaanxi Women's Legal Research and Service Center has been established as a multifaceted campaign against domestic violence. ${ }^{197}$ Also, the Jinghong Psychological and Legal Counseling Centre for Women and Children was recently established by the local women's federation and judicial bureau in Yunnan's southernmost prefecture of Xishuangbanna, bordering Burma and Laos. The six staff members, representing five different ethnic groups, come from diverse professional backgrounds including law, public administration, and education.

\section{IMPACT OF THE LEGAL AND ECONOMIC TRANSFORMATION ON WOMEN}

As Inga Markavitiz observes, the transition process from socialism to capitalism is an exchange of legal paradigms, with "state property replaced by private property; the plan by contracts; utopian hopes for substantive justice by a pragmatic reliance on procedure; collective man by the rights bearing individual. ${ }^{198}$ In the context of China, the transition from a planned to a market-oriented economy has resulted in change at the most fundamental level.

In the market-oriented economic era of the 1990s, China witnessed an increase in formal civil litigation and in the privatization of family and personal relations, as female litigants turned to the courts in petitioning for divorces. The formal legal process, more than informal mediation, focuses on the assertion of private, individual rights. Since adjudication captures moments of conflict and the institutional and social content of these moments, it is not only a source of private dispute resolution, but also a process by which public rights are determined and articulated. ${ }^{199}$ Chinese litigants, and especially Chinese women, have taken advantage of these moments. However, as so often happens when change is brought about on an individual basis, women are at a disadvantage. Now that state structures that once militated against

195. The Wuhan clinic advised over 8000 clients in 300 cases, offering services in five areas of specialization: women, children, disabled people, older people, and administrative cases, the latter involving disputes with governmental bodies.

196. There is now a national China Clinical Legal Educators Committee (CCLEC) under the auspice of China Law Society and funded by the Ford Foundation, which specifically addresses the issue of legal aid and clinical education in universities in China. This author sits as a member of the Advisory Board for CCLEC.

${ }^{197}$ Practice of Support Groups for Abused Women, DEMOCRACY \& LEGAL SYSTEM, supra note 43, at 32.

198. Inga Markivitz, Selective Memory: How the Law Affects What we Remember and Forget About the Past - The Case of East Germany, 35 LAW \& SOC'Y REV. 3, 543 (2001).

199. Lon L. Fuller, supra note 138 , at 363-65. 
discrimination have been dismantled, women may be left hostage to the prevailing gender bias.

Today, Chinese women are initiating divorces and exercising their rights under the Marriage Law. In so doing, they speak a new, personal language of "self-fulfillment" and express the view that divorce and marriage are private matters between two parties. Thus, they seek divorces when "emotions are broken," trying to avoid the prying eyes of the work unit and other collectivist organizations. The court process, in turn, treats women and men as autonomous individuals. Increasingly, Chinese judges are conducting fewer and fewer investigations, relying more on individual litigants to supply proof, and not ordinarily questioning the fairness of mediated outcomes.

In this way, then, the divorce process has not necessarily increased women's well-being. Since women on average face unequal economic powers and have fewer resources to make their stories heard, the movement toward a more adversarial system and the placement of burdens of proof on individual parties may not have worked to the advantage of most women. They face husbands hiding assets, the danger of being left homeless, and pressure to give up custody and property in the hopes of obtaining a simpler divorce. In the divorce litigation process, female litigants can face an uphill battle.

\section{A. 2001 Marriage Law Amendments}

Will women continue to utilize the rights accorded to them by the legal system? Will the system operate effectively to protect their rights? Some answers may be provided by the 2001 amendment to the Marriage Law. In China, state policies toward marriage reform and the dissolution of marriage have matched each period of social and political change. In the 1950s, the Marriage Law was heralded in to destroy the feudal establishment and reestablish the new socialist citizen. In 1980, the Marriage Law was again revised to redress the past abuses of the Cultural Revolution, and then operated together with changing economic policies to foster increasing use of the courts. The most recent ammendment of the Marriage Law, in 2001 perhaps reacted to the privatization of family and personal relations.

The new law, originally drafted by family law scholars, was unprecedented in terms of the quantity of public debate and comments solicited prior to its enactment by the NPC. The Women's Federation was a leading force in its adoption. The 2001 Marriage Law clarified the grounds for divorce, defined what constitutes marital property rights, ${ }^{200}$ and identified parental custody and visitation rights.

200. The Marriage Law (2001) provides that prenuptial property remains the individual property of the husband or wife, and lists the property acquired during the period of the marriage as joint property (this includes wages and bonuses; proceeds of production and business; proceeds of intellectual 
Significantly, the 2001 amended Marriage Law attempted to address some areas where women had faced problems within the operation of the 1980 Marriage Law. In many ways, the amended law reverts back to a more moralistic fault-based system with a renewed focus on collectivist mechanisms. So, for example, the 2001 Marriage Law provides for punishment of a party who attempts to conceal joint property to prevent a fair division of property in divorce, and further, allows a party without fault the right to request compensation from a spouse who has committed bigamy, illegal cohabitation, family violence, or desertion. ${ }^{201}$ In a tone that is reminiscent of the collectivist era, one commentator noted that this provision is necessary because "marriage and family" are the "cell" of society, and its "stability is foundational to society's stability."

Interestingly, there are also procedural provisions of the new law that augur a return to community control mechanisms. As mentioned earlier, the 2001 Marriage Law deals squarely for the first time with domestic violence. Significantly, the provision brings the issue of domestic violence into the public sphere and places it within the authority of the courts. Judges can no longer hide behind the old proverb, "qingguan nanduan jia wushi," (even the wisest judge cannot rule on family matters). In redressing domestic violence, the 2001 Marriage Law emphasizes both collectivist and state remedies. Victims of domestic violence can petition to relevant organizations, such as residence committees and work units, for mediation, or alternatively, may seek criminal prosecution. ${ }^{203}$ While Chinese women facing domestic violence may seek the intervention of social organizations, they have to accept the accompanying influence of those organizations on the results in their cases.

The 2001 Marriage Law may be one measure by which the Chinese State attempts to swing the pendulum back from a more individualist focus to a more collectivist one. Whether the amended Marriage Law proves to be more effective in protecting women's rights, however, will depend on whether and how women continue to use the courts to protect their rights and whether the courts will in fact provide protection of those rights.

property, property acquired by inheritance; and other property that shall be jointly possessed). Marriage Law of the People's Republic of China (2001), art. 17, available at www.isolaw.com./jsp;law/LAWChapters.jsp?CatID $=277 \&$ LangID $=0 \&$ StatutesID.

201. See Marriage Law of the People's Republic of China (2001), art. 46, available at www.isolaw.com./jsp;law/LAW-Chapters.jsp?CatID =277\&LangID=0\&StatutesID

202. Indeed, the guiding principle of divorce and marriage law is that marriage is the basis of fämily, and family makes up social "cells." "The stability of marriage and family, therefore, directly or indirectly influences social stability." Xiaoqing Feng, A Review of the Devlopment of Marriage Law in the People's Republic of China, 79 U. DET. MERCY L. REV. 331, 368 (2002).

203. See Marriage Law of the People's Republic of China (2001), art. 43, available at www. isolaw.com./jsp;law/LAW-Chapters.jsp?CatID=277\&LangID=0\&StatutesID. 


\section{CONCLUSION}

Ultimately, formal law and legal procedures by themselves are insufficient. China must determine what priority it will give to equality, women's rights protections, and other redistributive goals, even when these goals conflict with other state goals, such as economic development and nation-building. China's social priorities are especially tested when the hierarchy of conflicting social goals is determined through the enforcement of formal legal provisions.

There is also room for greater institutional support for the enforcement of existing enacted equality rights. There must be greater legal aid assistance and other safety-net organizations. The present distribution of legal services presents clear obstacles to the assertion of rights. The opportunity to assert rights should not be determined by markets or geography, but rather by concepts of justice.

China, like other transitional economies, faces the flip side of development, with widening income gaps and increased social stability. Greater access to legal aid and the availability of means of redress under the law are critical to ensure equal assertions of rights and claims to justice. Additional legal education programs are needed, not only to determine what women's substantive rights are, but also to how to enforce them. Such programs should be addressed not only to Chinese women, but also to the entire legal system. Indeed, the market will not provide any greater protection for women unless old social institutions adopt new practices, or newly-established social institutions become more conducive to rights assertion and the continuing recognition of the importance of equality. True legal reforms cannot take place until the culture of legal rights and the enforcement of these rights are firmly engrained and entrenched in each and every ordinary citizen. 